\title{
Effects of Melatonin, Progestagens, and the Ram on Out-of-Season Reproduction in Swedish Landrace Finewool Sheep
}

\author{
By P.J. Gates ${ }^{1}$, T. Henningsson ${ }^{1 \dagger}$, G. Tengroth ${ }^{1}$ and M. Forsberg ${ }^{2,3}$ \\ ${ }^{1}$ Department of Anımal Breedıng and Genetıcs, ${ }^{2}$ Department of Clinical Chemıstry, and ${ }^{3}$ Centre for Reproduc- \\ tıve Bıology, Swedısh Unıversity of Agrıcultural Scıences, Uppsala, Sweden.
}

\begin{abstract}
Gates PJ, Henningsson T, Tengroth G, Forsberg M: Effects of melatonin, progestagens and the ram on out-of-season reproduction in Swedish Landrace Finewool Sheep. Acta vet. scand. 1998, 39, 499-510. - One hundred twenty-one Swedısh Landrace Finewool ewes were treated with progestagen sponges $(\mathrm{P})$, teaser ram stimulation (R), or melatonın implants plus teaser ram stımulation $(M)$ in preparation for breeding with whole rams in August. Blood progesterone analyses from ewes in the $\mathrm{R}$ and $\mathrm{M}$ groups gave no evidence of luteal activity before the introduction of teaser rams. There were no significant differences between treatments for pregnancy rate ( $90 \%)$. The $\mathrm{P}$ group had the most compact lambing season, while median breeding dates for $\mathrm{M}$ and $\mathrm{R}$ groups were delayed by one cycle. In those groups, the introduction of breeding rams was later found to have been too late. $M$ and $R$ differed significantly for probable conception date but not for lambing dates. Circa $30 \%$ of $M$ ewes did not have a short 6 day ovulation cycle after the first ovulation, which resulted in a less concentrated lambing season than the other methods. Although no significant differences in litter size were seen among the 3 treatments, $M$ had the highest group average, 2.25. The ewes in this study were not in very deep anestrous in the middle of August. This supports the conclusion that treatment with exogenous hormones is not necessary to breed Swedish Landrace Finewool ewes successfully in late August/early September
\end{abstract}

ewes; breeding season; reproductive performance.

\section{Introduction}

Sheep are normally polyestral seasonal breeders (Hafez 1974). Ewes from breeds that originated in the temperate zones exhibit an annual pattern of estrus beginning in the fall followed by a period of anestrus that lasts from late winter or early spring until the next fall. The length and timing of the breeding season can vary between breeds (Wheeler \& Land 1977), environments, and location (Hulet et al. 1974). This leads to difficulties for the lamb producer.

$\dagger$ deceased November 26, 1995.
While seasonal reproductive patterns might be optimal in respect to pasture availability, the market usually has trouble absorbing the total annual production of fresh lamb in a few months. Because of this, interest has in recent years been focused on methods to induce ovulation and estrus outside the natural breeding season.

One technique for starting ovulation and estrus in ewes outside the normal season involves the use of a synthetic form of progesterone, progestagen, together with equine chorionic go- 
nadotropin (eCG). Progestagen is administered via pessaries that are inserted in the vagina and withdrawn after 10-12 days (Christenson 1976, Cognie \& Mauleon 1983, Haresign 1978). eCG is injected intradermally while the progestagen pessaries are still in the ewes. Falling levels of progestagens serve as an initial stımulus for ovulation in any phase of the reproductive cycle and have been primarily used to synchronize ewes. A high degree of control over both mating and lambing times is possible with progestagens alone if ewes are treated close to the start of the natural breeding season (Vipond \& King 1979, Quirke 1979). Later studies have shown that treatment with progestagens alone can also be effective for inducing out-of-season breeding in sheep (Wheaton et al. 1993).

Another method involves treatment with slow release implants of melatonin, a substance normally produced during the hours of darkness by the pineal gland. Melatonin acts as a link between the photoperiod and the reproductive system (Bittman \& Karsch 1984). As the number of hours of darkness decreases in the spring, the daily melatonin production also decreases, timing the onset of the breeding season later in the autumn (Malpaux et al. 1989). Treatment of anestrus ewes with melatonin implants in June and early July advances the onset of the breeding season (Durotoye et al. 1991, Haresign et al. 1990, Haresign 1990, Staples et al. 1992, Williams et al. 1992).

The "ram effect" is also a method of inducing anovulatory ewes to ovulate and show estrus. With this technique, ewes to be bred are separated from rams. Pheromonal and visual cues from the sudden reintroduction of rams stimulate an almost immediate surge in luteinizing hormone. If this ram stimulus is maintained long enough, most ewes ovulate within a day without showing estrus. In a proportion of ewes the resultant CL regresses after only 6 days and the ewe ovulates again. Normal luteal function follows this ovulation and estrus is shown at the next ovulation. In these ewes peak breeding activity is expected around 25 days after initial ram introduction. Ewes which do not exhibit short cycles show peak breeding activity around 19 days following ram introduction (Martin et al. 1986).

The Swedish meat packing industry has only recently showed an interest in the production of lamb outside the normal season. Previously, most of the carcasses from the fall lamb slaughter have been frozen in on a large scale. This proved to be too expensive when Swedish per capita consumption was low. A recent upswing in consumer perception of lamb as a trendy, upscale food has created an improved market for the fresh, domestic product year round. Most slaughter cooperatives have set up programs that offer premium prices for lamb delivered during periods of peak demand, spring and early summer. To participate, the producer signs a contract in advance to deliver a given number of lambs of a uniform size and slaughter classification in a designated week. Obviously, any viable production system will be dependent on reliable methods of breeding ewes out of season that also give a concentrated lambing season. Other desirable features of economic concern are the lambing percentage and ovulation rate/litter size. Both are less than optimal outside the normal season (Gates 1991, Fogarty et al. 1984, Hulet et al. 1974).

The purpose of this investigation was to compare the effects of progestagen sponges, melatonin implants and the ram effect on the number of ewes lambing, litter size, and distribution of lambing dates in Swedish Landrace Finewool ewes bred in August.

\section{Materials and methods}

Experimental Design

In all, 121 Swedish Landrace Finewool ewes from the flock at Lövsta experimental station, 
$59^{\circ} 50^{\prime} \mathrm{N}$, were used in this experiment. All of them had lambed during the previous "normal" lambing season, between March 30 and April 25. The average litter size then was ca. 1.9 lambs per ewe for those lambing as yearlings and 2.7 lambs per ewe for the older ewes. Lambs from the previous lambing season were weaned as a group on July 17. Before weaning, ewes were allotted to 3 treatment groups so that the average age in each group was roughly similar. The groups were then physically separated from each other so that they were out of sight and hearing distance on pasture and with walls once they came into the barns. This was done to avoid the possibility of an earlier group stimulating and synchronizing a later group. Other workers have confirmed that contact with another group of sexually active ewes can affect the number of ewes that respond to rams during anestrus (Nugent \& Notter 1990).

The ewes were bred by 11 proven Swedish Landrace Finewool, Swedish Crossbred, and Texel rams, all of which had settled ewes the season before. Further stimulation of the rams was provided by exposing them to a separate group of progestagen synchronized ewes for 5 days immediately preceding the breeding period. Ewes were further divided into smaller groups of 3 or 4 within the treatment group so that each ram was allotted a small ewe group from each of the
3 treatment groups. Rams rotated among their ewe groups daily. Visual observations of mating were made in the first $30 \mathrm{~min}$ after rams entered a ewe group. Ewes were inspected for crayon marks from marking harnesses after rams left a ewe group. Not all ewes that eventually lambed had an observed mating. A preliminary conception date was calculated as having occurred 145 days before lambing. The probable ovulation date associated with conception was estimated to be the preliminary conception date for animals without recorded matings while the same date was determined to be the date for the recorded mating closest to the preliminary conception date. If a ewe had mating records on more than one day within a 5 day period close to the preliminary conception date the probable conception date was taken to be the date for the last recorded observation. Furthermore, probable ovulation dates previous to conception were calculated by counting backwards 17 days (one sexual cycle) from the estimated ovulation date associated with conception. For most ewes this could be repeated until the previous ovulation date was within 6 days of the teaser ram introduction.

\section{Treatments}

Treatments were originally planned so that the breeding season for each group should have be-

Table 1. Treatment schedule for early mated Swedish landrace finewool ewes.

\begin{tabular}{llll}
\hline & \multicolumn{3}{c}{ Treatment groups } \\
\cline { 2 - 4 } Activity & Melatonın & Progesterone & Ram effect \\
\hline Implantation Prime-X & June 25 & & \\
Teaser ram, introduction & July 19-22, & & July 20-23, \\
July 29-August 9 & July 30 & July 29-August 9 \\
Sponge insertion & & August 6 & \\
Sponge removal & August 9 & August 9 & August 9 \\
Brought into barn & August 13 & August 13 & August 13 \\
Breeding ram introduction & September 24 & September 24 & September 24 \\
Breedıng ram removal & & &
\end{tabular}


gun simultaneously for all groups. A schedule of all 3 treatments is shown in Table 1.

The melatonin group was implanted with 2 PRIME-X ${ }^{\circledR 1} 12 \mathrm{mg}$ implants near the base of the ear. Both the melatonin and the "ram" groups were exposed to vasectomized rams between July 19 and July 23 and between July 29 and August 9. This is the procedure recommended to Swedish sheep producers for synchronization of breeding with the "ram effect". The sponges used on the "progestagen" group contained $40 \mathrm{mg}$ of flourogestone acetate.

\section{Progesterone Assay}

Blood samples were taken from 8 ewes from the melatonin group and 8 from the "ram" group weekly, starting on June 27 and continuing until September 26. Animals were chosen for blood testing to get uniform groups with respect to age. The weekly testing schedule is not 1deal, but was adopted primarily for economic reasons. Most ewes ovulate without showing estrus within a few days after initial exposure to rams. A proportion of the resultant corpora lutea regresses after only 5 to 6 days, however (Knight et al. 1981). The following ovulation then produces more corpora lutea that are maintained for the normal length of an ovine reproductive cycle, 17 days. With the weekly bleeding schedule used here the smaller upsurge in progesterone from the first corpora lutea that regresses prematurely can be missed entirely.

Blood was collected into heparinized tubes between 12:00 $\mathrm{h}$ and 13:00 $\mathrm{h}$ each tıme. Plasma was frozen and later assayed for progesterone $\left(\mathrm{P}_{4}\right)$ by luminescence immunoassay (Amerlite; Kodak Clinical Diagnostıcs Ltd., England). According to the manufacturer, the antiserum is highly specific for $\mathrm{P}_{4}$ with very low cross-reac-

\footnotetext{
1 PRIME-X, Wildlıfe Pharmaceuticals, Inc., Fort Collıns, Colorado, USA.
}

tivity to other structurally related compounds. Standards and controls were provided in human serum. Duplicate aliquots of $25 \mu \mathrm{l}$ standards, controls, and plasma samples, followed by 100 $\mu \mathrm{l}$ of HRP-labeled hormone and $100 \mu \mathrm{l}$ antiserum were pipetted into the wells. The wells were covered with a lid and placed in the Amerlite Shaker Incubator at $37^{\circ} \mathrm{C}$. After no more than $5 \mathrm{~min}$, the wells were aspirated and washed in the Amerlite Washer. Immediately after washıng, $250 \mu$ l of signal reagent was dispensed into all wells. The wells were read in the Amerlite Analyzer $5 \mathrm{~min}$ after addition of signal reagent.

Serial dilutions of ovine plasma containing high concentrations of $\mathrm{P}_{4}$ produced curves parallel to the standard curve. Sensitivity of the assay system was $<0.5 \mathrm{nmol} / 1$. Intra-assay variation for $\mathrm{P}_{4}$ was $13.5 \%$ and $6.0 \%$ for low and high assay controls. The corresponding inter-assay variation was $10.0 \%$ and $8.4 \%$.

A base level for progesterone levels during the anestrus period was calculated as follows: the standard deviation was calculated for progesterone levels before the introduction of rams. The base level was then set as 2 standard deviations above zero or $1.15 \mathrm{nmol} / \mathrm{l}$. Evidence of luteal actıvity was defined as progesterone levels greater than $2 \mathrm{nmol}$./1.

\section{Statistical Methods}

Dates and progesterone levels are summarized for groups as medians. This measure of centrality was chosen for both its robustness and because of the nonnormal distribution of the data. Homogeneity between the treatments and the binary outcome pregnant/not pregnant was tested with Pearson's chi-square statistic (Freeman 1987). Since litter size is an ordinal multinomial response, litter s1zes were considered as Wilcoxon rank scores. The null hypothesis that the sum of scores for every level of treatment would be equal was tested with the Kruskal- 
Wallis approximate chi-square statistic (Sprent 1989). Differences between groups for probable conception day and lambing date were also analyzed as Wilcoxon rank scores. When comparing only the "ram" group with the melatonin group, the scores where tested by the Wilcoxon sample test for two samples with a continuity correction of 0.5 . All statistical analyses were done with SAS procedure NPAR1WAY (SAS Institute Inc. 1989).

\section{Results}

Results of the progesterone analyses are summarized in Figs. 1a and 1b. Ewes in the melatonin and "ram effect" groups were not cycling spontaneously before the introduction of the teaser rams. Melatonin treated ewes were seen to have started cycling earlier than "ram effect" ewes in Figs. 1a and $b$. The melatonin group even displayed higher progesterone levels than the "ram effect" group throughout the reproductive cycle, especially after pregnancy was established. Tests for significant differences in progesterone levels between treatment groups were not feasible due to the small number of observations in each group and the weekly blood sampling schedule.

Effects of the different treatments on fertility are seen in Table 2. There was no significant difference in pregnancy rate between treatments.

The distributions of lambing dates for the different treatments are seen in Fig. 2. Clearly, the progestagen group had the most concentrated lambing season with the first $80 \%$ of all lambings taking place in the first 6 days. The pattern of lambings was delayed for the melatonin and "ram" group, taking approximately a month to lamb the first $80 \%$, with the "ram" group lagging behind the melatonin group by nearly a week. It is apparent from Fig. 2 that the ram stimulation programs used for the melatonin and the "ram effect" treatments did not work as anticipated. The sterilized teaser rams were to have stimulated the ewes in these 2 groups so that the first estrus periods should have been synchronized with the progestagen group. Instead, the median probable conception dates for the melatonin and "ram effect" groups were August 30 and September 4, respectively, 17 and 22 days after the introduction of breeding rams. Significant differences were seen between the ranks for probable conception date for ewes in the melatonin and "ram effect" groups (prob. $=0.033$ ) but not between the ranks for lambing dates (prob. $=0.129$ ). Although the melatonin treated ewes as a group were estimated to have conceived significantly earlier, there was no significant difference in lambing dates.

Fig. 2 also reveals that some of the ewes in the melatonin group ( $\sim 30 \%$ ) probably did not have short cycles after ram stimulation. A better illustration of this is to be found in the plotted progesterone values and probable ovulation dates for individual ewes in Figs. $3 a$ and $3 b$. Ewe 825 (lambing date, Jan. 22) would show a pattern of ovulation typical of the large group that lambed after January 22. Her last probable ovulation date is estimated from a record of the mating that resulted in conception. Estrus in the previous cycle had most likely preceded the introduction of the breeding ram by 2 days. Progesterone levels indicate that one more ovulation could have taken place before this at roughly 6 days after the initial introduction of the teaser ram. This would be the result of a premature regression of the first corpora lutea in the breeding season. On the other hand, ewe 809 (lambing date, Jan. 15) showed estrous and was bred on August 22. Higher levels of progesterone indicate an ovulation roughly 17 days earlier. This first ovulation also took place 17 days after the introduction of the teaser ram, with no evidence of any earlier activity. 

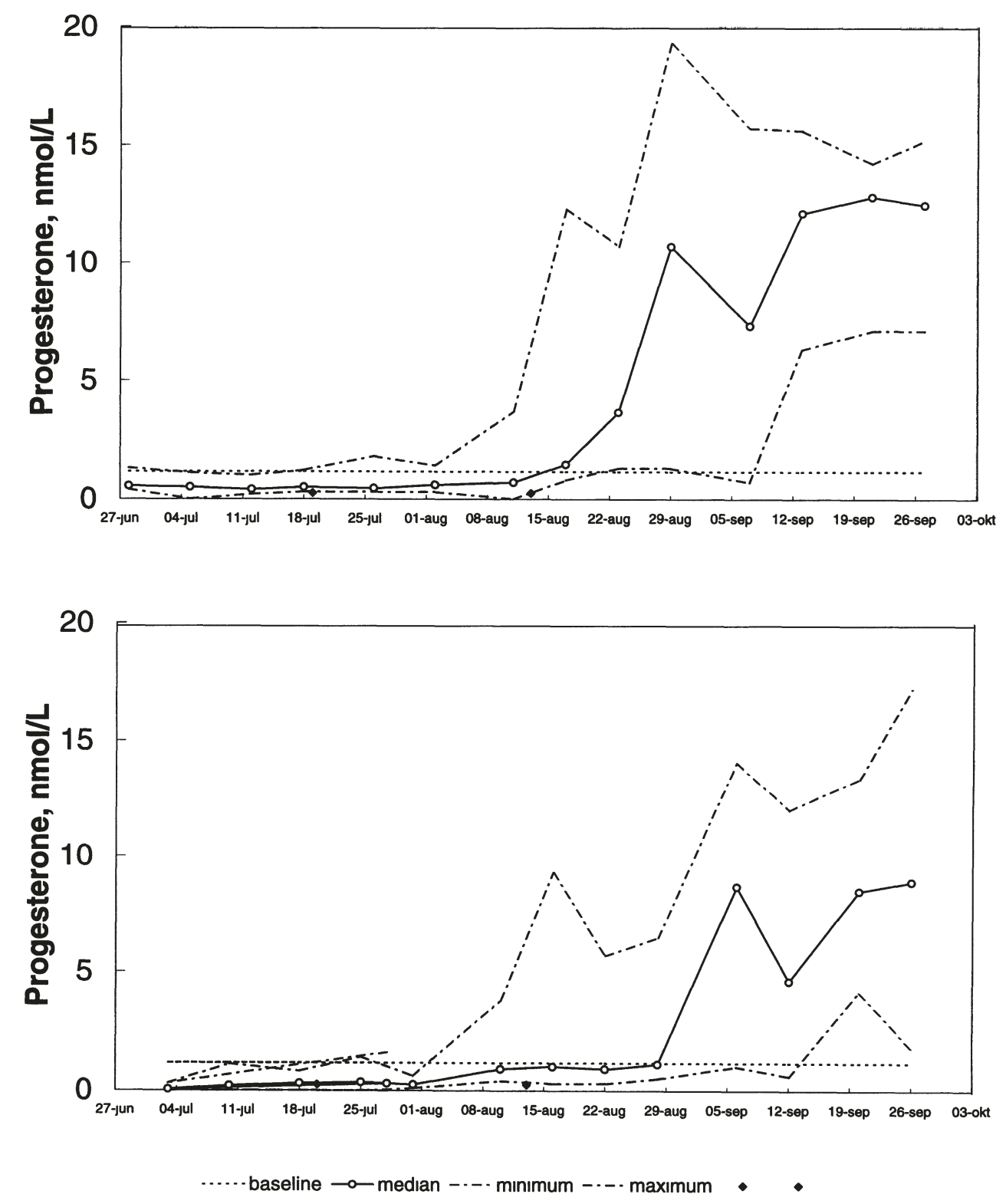

Figure $1 \mathrm{a}-\mathrm{b}$. Median and mınımum/maxımum for progesterone concentrations measured for ewes stımulated to breed out of season with either melatonin implants (a) or the "ram effect" (b). The horizontal line at 1.15 $\mathrm{nmol} / \mathrm{l}$ represents a baseline below which it is assumed that there is no progesterone production. The diamonds $(\diamond)$ indicate introduction dates for both the teaser rams (July 19 for the melatonin group and July 20 for the "ram effect" group) and the breeding rams (August 13 for both treatment groups) 


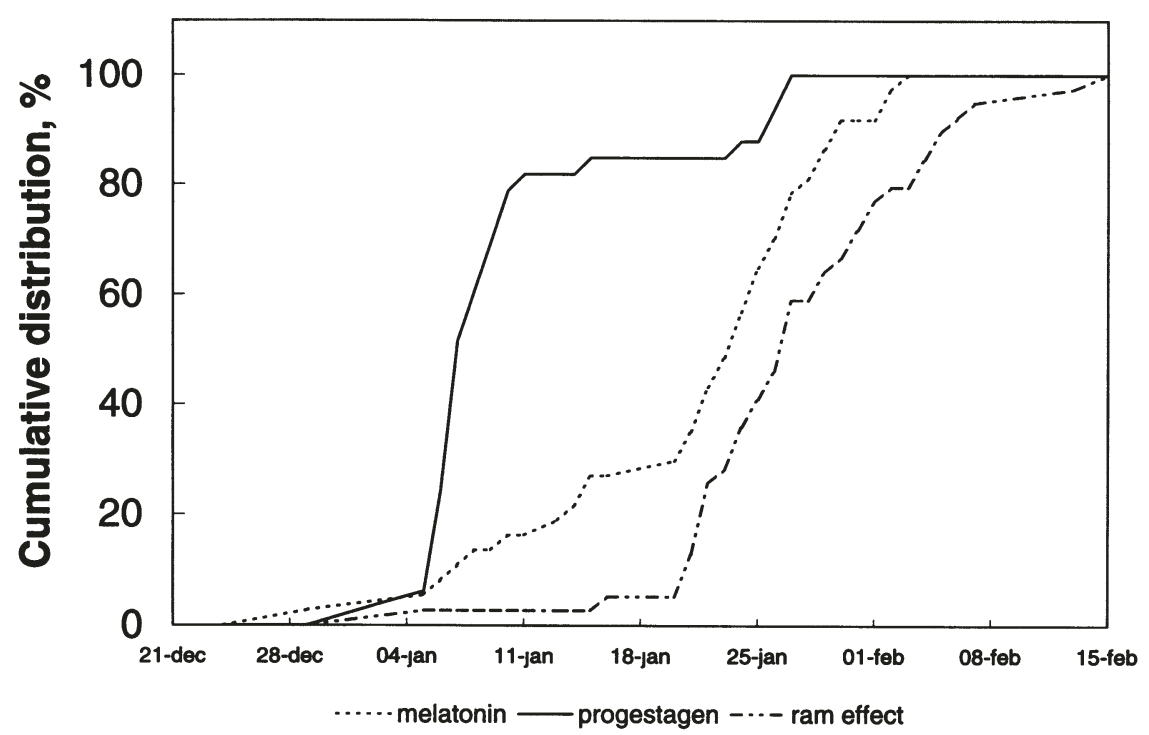

Figure 2 Cumulative distribution for lambing dates of ewes stimulated to breed out of season with one of the following 3 treatments. progesterone, melatonin implants and the "ram effect".

Table 3 presents the effects of treatment on litter size in those ewes that did lamb. Ewes treated with melatonin had the largest average litter sizes (2.25), while the progestagen and "ram effect" groups had slightly lower average litter sizes, 1.97 and 2.05, respectively. Litter sizes in the progestagen group were much more concentrated around 2.0 than the other treatment groups. No significant difference between treatment groups was seen (prob. $=0.204$ ).

\section{Discussion}

The insignificant advantages for melatonin on pregnancy rate shown here are similar to results for Mule ewes obtained in other studies (Haresign 1992, Durotoye et al. 1991, Wallace et al. 1988). A larger investigation of melatonin confirmed this on a variety of breeds in lowland flocks (Haresign et al. 1990). An upland flock of Scottish Blackface ewes in the same study, however, showed significant advantages for melatonin treated ewes over nontreated controls in the proportion of ewes mated. It may be that melatonin has more effect on pregnancy rates in more seasonal breeds. The Swedish Landrace Finewool breed is not known among Swedish sheep producers for being especially seasonal. Preliminary studies in the same flock have confirmed this.

That melatonin treatment advanced the median date for probable conception but not the median lambing date has also been reported for Mule ewes in another study (Durotoye et al. 1991). There, melatonin treated ewes mated on the average 7 to 10 days earlier than nontreated con-

Table 2. Effect of treatment on pregnancy rate.

\begin{tabular}{lccc}
\hline \multirow{2}{*}{ Treatment } & \multicolumn{2}{c}{ No of ewes } & \multirow{2}{*}{ Preg \% } \\
\cline { 2 - 3 } & Preg & Not preg & \\
\hline Ram effect & 39 & 5 & 88 \\
Melatonin & 36 & 4 & 90 \\
Progestagen & 33 & 4 & 89 \\
Total & 108 & 13 & 89 \\
\hline
\end{tabular}



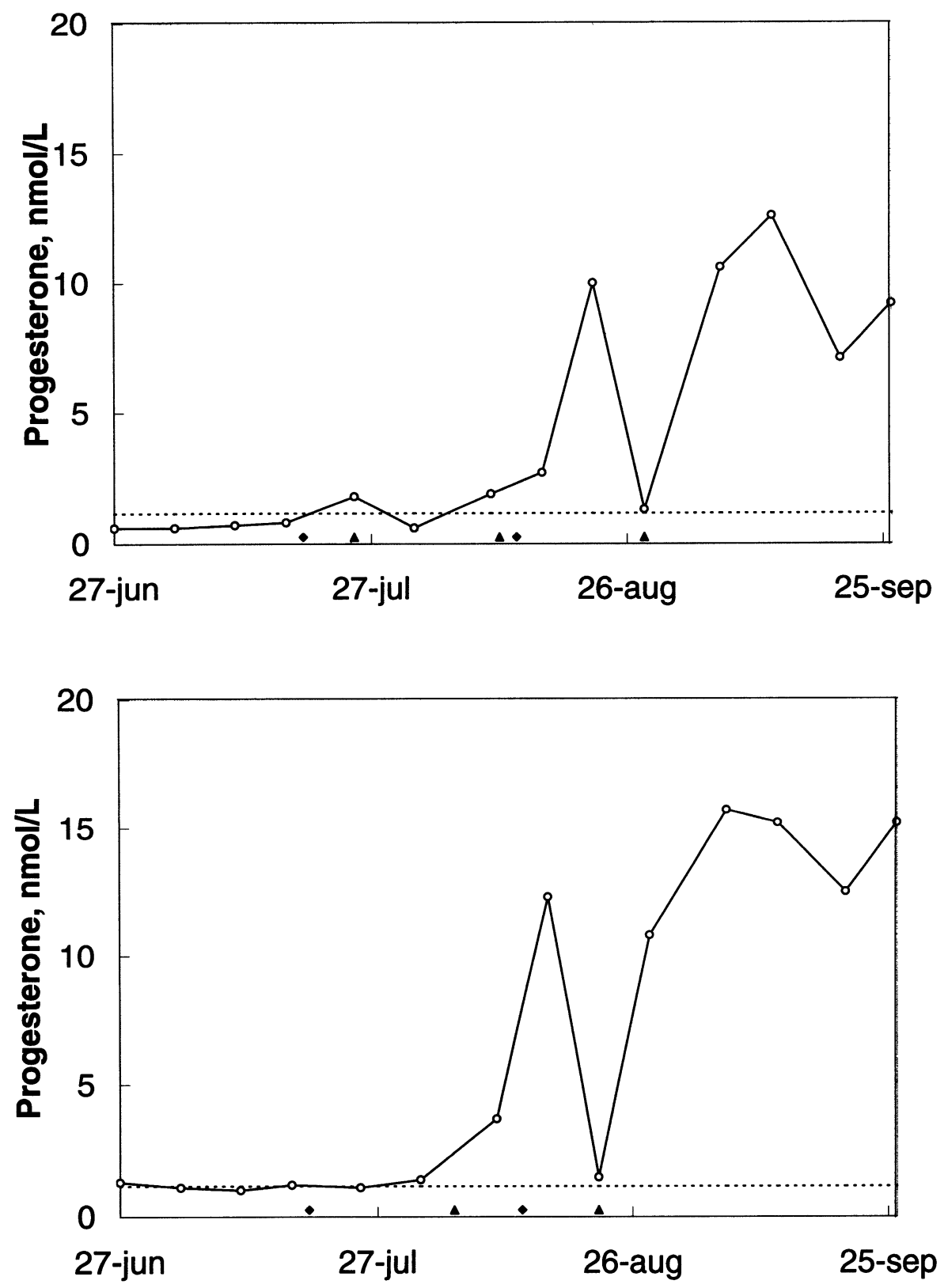

Figure $3 \mathrm{a}-\mathrm{b}$. Progesterone concentration and probable ovulation dates for 2 ewes stımulated to breed out of season with melatonin implants: ewe 825 (a) and ewe 809 (b). The horizontal line at $115 \mathrm{nmol} / 1$ represents a baseline below which it is assumed that there is no progesterone production. The diamonds $(\diamond)$ indicate introduction dates for both the teaser rams (July 19) and the breeding rams (August 13) 
Table 3 Effect of treatment on litter size distribution and mean.

\begin{tabular}{lcccccc}
\hline \multirow{2}{*}{ Treatment } & \multicolumn{5}{c}{ Litter size distribution } & \multirow{2}{*}{ Mean } \\
\cline { 2 - 6 } & 1 & 2 & 3 & 4 & 5 & \\
\hline Ram effect & 8 & 23 & 6 & 2 & 0 & 2.05 \\
Melatonin & 4 & 21 & 10 & 0 & 1 & 2.25 \\
Progestagen & 3 & 28 & 2 & 0 & 0 & 1.97 \\
\hline
\end{tabular}

trols, while the average lambing date was advanced by only two days. Small but significant reductions are reported in the time it took melatonin treated Mule and Suffolk ewes to display estrus in some flocks, but not in others (Haresign et al. 1990). While some researchers have seen only small differences for purebred Merino and Merino crossbred ewes (Williams et al. 1992), others could not find any difference between melatonin treatment and teaser rams in the advancement of first estrus in the same breed (Staples et al. 1992). Scottish Blackface ewes treated with melatonin via an oral drench, on the other hand, went into estrus considerably earlier than their untreated counterparts ( Wallace et al. 1988). Melatonin treatment did not significantly affect ovulation dates of ewes exposed to rams in the same study. One research team has concluded that most of the advancement and tightening up of the lambing season associated with melatonin treatment is mainly due to an improved "ram effect" (Williams et al. 1992). On the basis of this study and the studies cited above it is tempting to speculate if treatment with constant release melatonin does not lengthen behavioral estrous but leaves the time of conception untouched. If this were so, the calculations for the probable ovulation dates might be systematically biased for the melatonin treatment group. This could be a result of the higher levels of progesterone seen for ewes treated with melatonin. Increased progesterone levels are a prerequisite for behavioral estrous in the ewe. Further studies designed to test just this hypothesis would be necessary to confirm and quantify this.

While the use of melatonin shortened the time between the introduction of the ram and the median conception date, it also spread out the lambing season since some of the melatonin treated ewes did not have a short cycle immediately following the initial ovulation without estrus. Other researchers have reported significant advances in ovulation dates and a tighter distribution of ovulation dates for melatonin treated Border Leicester $\times$ Scottish Blackface crossbred ewes in the absence of rams (Robinson et al. 1991). Results from another study suggest that these differences might be dependent on the time of implantation for melatonin (Haresign 1991).

Staples et al. (1992) recommend that fertile rams be introduced 40 days after treatment with slow release melatonin. Fertile rams should then stimulate silent ovulations in the ewes after 6 days followed by an ovulation with estrus 17 days later, roughly 22 days after introduction of the ram or 62 days after the initial melatonin treatment. This protocol was not followed in this trial. Vasectomized rams were first turned in to the melatonin treatment and the "ram effect" groups and then followed by fertile rams after 22 days. It was thought that the first contact with teaser rams would stimulate a certain percentage of short 6 day cycles. The reintroduction of new fertile rams was to have restimulated ewes to lyse stable corpora lutea so that a larger proportion of the group would have 
been synchronized 17 days later. This did not work. It seems as if the initial effects of exposure to rams set separate patterns for cycling for 2 subgroups of ewes, one with an initial short 6-day cycle and one without.

Melatonin implants give the ewe a short day signal that must be preceded by a long day signal to produce any noticeable differences in reproductive function (O'Callaghan et al. 1991). Implantation before an adequate long day signal is received by the ewe has been extensively documented as inefficient in advancing the breeding season in the anestrus ewe (Williams et al. 1992, Durotoye et al. 1991, English et al. 1986). An extensive review of several melatonin trials concluded that the "window" for effective melatonin treatment in less-seasonal breeds starts earlier in the year than for more seasonal breeds (Staples et al. 1992). Effects of melatonin treatment will also tend to diminish as the start of the normal breeding season approaches. It is entirely possible that the date for melatonin implantation (June 25) in this study was later than the optımal window for treatment in this breed. Larger responses for melatonin might have been obtained if the objective had been to breed ewes earlier. Treatment would have been started earlier.

There are several studies that mention modest increases in average litter size in connection with melatonin treatment (Williams et al 1992, Haresign 1992, Robinson et al. 1991, Durotoye et al 1991, Haresign et al 1990). Several breeds were included in these studies. These increases are often insignificant for less seasonal breeds and for ewes in favorable environments. Melatonin treated ewes have been shown to have higher levels of endogenous progesterone during luteal activity than either progestagen treated ewes or ewes exposed to the "ram effect" (Wallace et al. 1988). The small litter size increases that are usually associated with melatonin treatment are thought to stem from this.
The results of the progesterone analyses and the pregnancy rates obtained in this study suggest that Swedish Landrace Finewool ewes go into anestrous but it is not especially deep. This made it relatively easy to induce estrus and settle most ewes in August with all 3 methods. The fact that there were few significant differences between the "ram effect" and the treatments that involved exogenous hormones points out the suitability of the Swedish Landrace Finewool ewe as a producer of lamb outside the ordinary season.

The method of choice for inducing ovulations and estrus will depend largely on the breed of ewe and the preferences of the individual producer. Of the 2 methods that involved exogenous hormone treatments, melatonin gave a higher percentage of litter sizes larger than 2 , while litter sizes for progestagen were strongly concentrated around two. Even at their best, methods that rely on rams to advance the breeding season will probably not give as compact a lambing season as progestagen. More work needs to be done in this area, especially on estrus synchronization. Any gains from increased litter size attributed to melatonin treatment might be canceled by the increased spread in lambıng dates. Differences between melatonın and the "ram effect" in this application are so slight that it is questionable if the extra labor and costs incurred by melatonin are justified for the Swedish Landrace Finewool breed. The above conclusions do not necessarily apply to other Swedish breeds, such as the highly seasonal Swedish Pelt Sheep. Separate investigations would be needed if an interest in producing lamb out of season with those breeds ever arose.

\section{References}

Cognie Y, Mauleon P Control of Reproduction in the Ewe, In: Sheep Production (Nottıngham Easter 
School proceedings) 35 Butterworths, London, 1983, 381-392

Durotoye LA, Rajkumar R, Argo CM, Nowak R, Webley GE, McNell ME, Graham NB, Rodway RG: Effect of constant-release melatonin implants on the onset of oestrus activity and on reproductive performance in the ewe. Anım. Prod 1991, 52, 489-497

English J, Poulton AL, Arendt J, Symons AMA A comparison of the efficiency of treatments in advancing oestrus in ewes. J. Reprod. Fert. 1986, 77, 321-327.

Fogarty NM, Dickerson GE, Young LD Lamb production and its components in pure breeds and composite lines. I Seasonal and other environmental effects. J. Anım Sci. 1984, 58, 285300.

Freeman $\mathrm{DH}$. Applied Categorical Data Analysis Marcel Dekker, Inc., New York and Basel, 1987, 81-94.

Gates PJ Effects of season on ewe productivity. Proceeedıngs 42nd annual EAAP meetıng. Berlın, 1991, 2, 268-269 abstr

Hafez ESE. Reproduction in Farm Anımals. Lea and Febiger, Philadelphia, 1974, 92-94.

Haresign $W$ The effect of implantation of lowland ewes with melatonin on the time of matıng and reproductive performance. Anım. Prod. 1992, 54, 31-39.

Haresign $W$ Ovulation control in the sheep In: Control of Ovulation (Nottıngham Easter School proceedıngs) 26, Butterworths, London, 1978, 435451.

Haresign W, Peters AR, Staples LD. The effect of melatonin implants on breeding actıvity and litter size in commercial sheep flocks in the UK. Anim Prod. 1990, 50, 111-121.

Hulet CV, Price DA, Foote WC Effects of month of breeding and feed level on ovulation and lambing rates of Panama ewes. J. Anım Sci 1974, 39, 7378.

Hulet $C V$, Shelton M, Gallagher JR, Price DA Effects of origin and environment on reproductive phenomena in Rambouillet ewes I. Breeding season and ovulation J. Anım. Sc1. 1974, 38, 12101217.

Knight TW, Tervit HR, Fairclough RJ Corpus luteum function in ewes stımulated by rams. Thenogenology 1981, 15, 183-190

Malpaux B, Robinson JE, Wayne NL, Karsch FJ Regulation of the onset of the breeding season of the ewe: importance of long days and of an en- dogenous reproductive rhythm. J. Endocrinol. 1989, 122, 269-278.

Martın GB, Oldham CM, Cognie Y, Pearce DT The physiological responses of anovulatory ewes to the introduction of rams- a review. Livest. Prod. Sc1 1986, 15, 219-247.

Nugent RA, Notter DR Effect of cohabitation with white-faced ewes on estrous activity of hampshire and suffolk ewes exposed to rams in june. J Anım. Sc1. 1990, 68, 1513-1519

$O$ 'Callaghan DO, Karsch FJ, Boland MP, Roche JF. What photoperiodic signal is provided by a contınuous-release melatonin implant? Biol Reprod. 1991, 45, 927-933.

Quirke JF Control of repoduction in adult ewes and ewelambs and estımation of reproductive wastage in ewe lambs following treatment with progestagen impregnated sponges and PMSG. Livest. Prod. Sc1. 1979, 6, 295-305.

Robinson JJ, Wigzell S, Attken RP, Wallace JM, Ireland $S$, Robertson IS The modifying effects of melatonin, ram exposure and plane of nutrition on the onset of ovarian activity, ovulation rate and the endocrine status of ewes. Anım. Reprod. Scı 1991, 26, 73-91.

Sprent $P \cdot$ Applied Nonparametric Statistical Methods, Second Edition. Chapman and Hall, London, 1989, 138-140.

Staples LD, McPhee S, Kenneway DJ, Willaams AH· The influence of exogenous melatonin on the seasonal patterns of ovulation and oestrus in sheep. Anım. Reprod. Sc1. 1992, 30, 185-223.

Vipond JE, King ME. Synchronisation of oestrus as an a1d to management in small flocks. Anım. Prod. 1979, 28, 447-451.

Wallace JM, Robinson JJ, Wigzell S, Attken RP Effect of melatonin on the peripheral concentrations of $\mathrm{LH}$ and progesterone after oestrus, and on conception rate in ewes. J. Endocr. 1988, 119 , 523-530.

Wheaton JE, Carlson KM, Windels HF, Johnston LJ CIDR: a new progesterone-releasing intravaginal device for induction of estrus and cycle control in sheep and goats. Anım. Reprod. Sc1. 1993, 3, 127-141.

Wheeler $A G$, Land $R B$ Seasonal variation in oestrus and ovarian activity of Finnish Landrace, Tasmanıan merıno and Scottısh blackface ewes. Anim. Prod. 1977, 24, 363-376.

Williams AH, McPhee SR, Reeve JL, Staples LD. Optımum use of subcutaneous melatonin implants to enhance the reproductive performance of sea- 
sonal and non-seasonal sheep joined in spring and early summer. Anım. Reprod. Sci 1992, 30, 225-258.

\section{Sammanfattning \\ Effekterna av behandling med melatonin, progesta- gener och "bagg effekten" på reproduktion utanför den normala säsong hos svenska lantrasfinulltackor}

120 lantrasfinullstackor slumpades ut t1ll en av tre behandlıngsgrupper för utvärderıng av alternatıva sátt att framkalla ovulation och brunst 1 augusti. $P$ gruppen behandlades med progesteron tamponger, $R$ gruppen stımulerades med enbart proberbagge och $M$ gruppen injıcerades med långtıdsutsöndrande melatonın samt stımulerades med en proberbagge. Vid analys av progesteron i blodet kunde ingen förekomst av gulkroppar påvisas fore introduktıon av proberbaggar. De tre behandlıngsgrupperna visade ingen statıstıskt säker skıllnad 1 dräktıghetsprocent vılken var ungefar $90 \%$ för alla grupper. $P$ gruppen visade den mest koncentrerade lamningssäsongen medan medıan-lamnıngsdatum för både $M$ och $R$ var förlangd med en reproduktionscykel Vidare analys visade att de fertıla baggarna släpptes in till $R$ - och $M$ - grupperna för sent. Medianerna for $M$ och $R$ grupperna var statistiskt signifikant skılda för trolıgt befruktningsdatum men inte lamningsdatum. Ca $30 \%$ av $M$ tackorna fick inte en kort sexdagars ovulatıonscykel efter den första ägglossnıngen vilket resulterade 1 en mer utsprıdd lamnıngssäsong än för de andra behandlıngsgrupperna. Den högsta medelkullstorleken, 225 , påvisades hos $M$ gruppen, men inga statıstıskt säkra skıllnader kunde påvısas mellan grupperna Tackorna 1 studien var inte 1 en djup anöstral fas 1 mitten av augusti. Detta stodjer slutsatsen att det àr onödıgt att hormonbehandla svenska lantrasfinullstackor för att kunna betäcka dem med framgång sent 1 augustı eller tıdigt 1 september

(Recelved August 28, 1998; accepted September 17, 1998).

Reprints may be obtained from: P.J. Gates, Department of Anımal Breeding and Genetics, Swedish University of Agricultural Sciences, S-750 07 Uppsala, Sweden E-mail: peter.gates@hgen.slu.se, tel: +4618 6745 35, fax +4618674501 